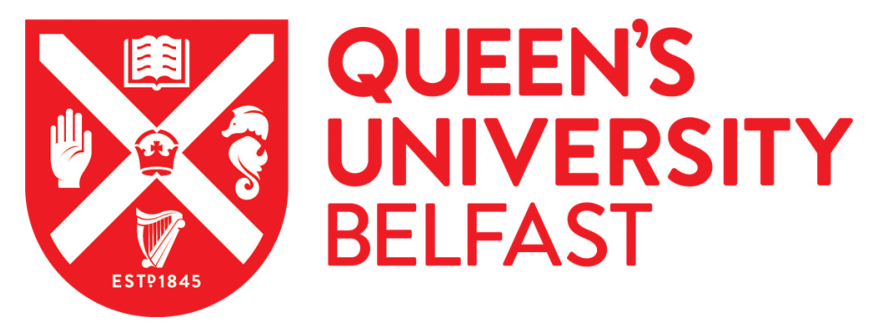

\title{
Combined studies of DFT atomistic modelling and in situ FTIR spectroscopy on surface oxidants and CO oxidation at Ru electrodes
}

Liu, B. Y., Jin, J. M., Hardacre, C., Hu, P., \& Lin, W. F. (2013). Combined studies of DFT atomistic modelling and in situ FTIR spectroscopy on surface oxidants and CO oxidation at Ru electrodes. Journal of Electroanalytical Chemistry, 688, 216-223. https://doi.org/10.1016/j.jelechem.2012.10.027

Published in:

Journal of Electroanalytical Chemistry

Document Version:

Peer reviewed version

Queen's University Belfast - Research Portal:

Link to publication record in Queen's University Belfast Research Portal

Publisher rights

NOTICE: this is the author's version of a work that was accepted for publication in Journal of Electroanalytical Chemistry. Changes resulting from the publishing process, such as peer review, editing, corrections, structural formatting, and other quality control mechanisms may not be reflected in this document. Changes may have been made to this work since it was submitted for publication. A definitive version was subsequently published in Journal of Electroanalytical Chemistry, [VOL 688, 2013]

\section{General rights}

Copyright for the publications made accessible via the Queen's University Belfast Research Portal is retained by the author(s) and / or other copyright owners and it is a condition of accessing these publications that users recognise and abide by the legal requirements associated with these rights.

Take down policy

The Research Portal is Queen's institutional repository that provides access to Queen's research output. Every effort has been made to ensure that content in the Research Portal does not infringe any person's rights, or applicable UK laws. If you discover content in the Research Portal that you believe breaches copyright or violates any law, please contact openaccess@qub.ac.uk. 


\section{Accepted Manuscript}

Combined studies of DFT atomistic modelling and in-situ FTIR spectroscopy on surface oxidants and $\mathrm{CO}$ oxidation at $\mathrm{Ru}$ electrodes

Journet of

Electroanalytical

Chemistry

B.Y. Liu, J.M. Jin, C. Hardacre, P. Hu, W.F. Lin

PII:

S1572-6657(12)00447-X

DOI:

http://dx.doi.org/10.1016/j.jelechem.2012.10.027

Reference:

JEAC 1070

To appear in:

Journal of Electroanalytical Chemistry

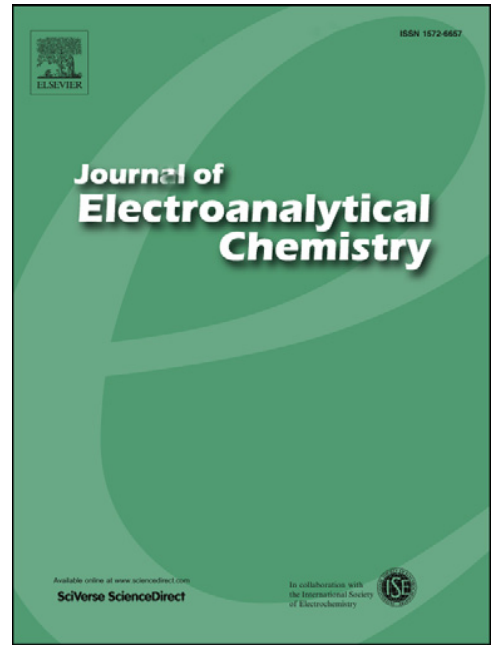

Please cite this article as: B.Y. Liu, J.M. Jin, C. Hardacre, P. Hu, W.F. Lin, Combined studies of DFT atomistic modelling and in-situ FTIR spectroscopy on surface oxidants and CO oxidation at Ru electrodes, Journal of Electroanalytical Chemistry (2012), doi: http://dx.doi.org/10.1016/j.jelechem.2012.10.027

This is a PDF file of an unedited manuscript that has been accepted for publication. As a service to our customers we are providing this early version of the manuscript. The manuscript will undergo copyediting, typesetting, and review of the resulting proof before it is published in its final form. Please note that during the production process errors may be discovered which could affect the content, and all legal disclaimers that apply to the journal pertain. 


\section{Combined studies of DFT atomistic modelling and in-situ FTIR spectroscopy on surface oxidants and CO oxidation at Ru electrodes}

B. Y. Liu, J. M. Jin, C. Hardacre, P. Hu, W. F. Lin ${ }^{*}$

Centre for the Theory and Application of Catalysis, School of Chemistry and Chemical Engineering, Queen's University Belfast, Belfast BT9 5AG, UK

\section{$\underline{\text { ABSTRACT }}$}

We report the combined studies of density functional theory (DFT) calculations and electrochemical in-situ FTIR spectroscopy on surface oxidants and mechanisms of CO oxidation at the $\mathrm{Ru}(0001)$ electrodes. It is shown that $\mathrm{CO}$ can co-adsorb with both $\mathrm{O}$ and $\mathrm{OH}$ species at lower potential region where a low coverage of the $(2 \times 2)-\mathrm{O} / \mathrm{OH}$ adlayer formed; the oxidation of $\mathrm{CO}$ adsorbates takes place at higher potentials where a high coverage of the (1 x 1)-O/OH adlayer formed. Surface $\mathrm{O}$ species are not the active oxidants under all coverages studied, due to the high reaction barriers between $\mathrm{CO}$ and $\mathrm{O}(>1 \mathrm{eV})$. However, surface $\mathrm{OH}$ species with higher coverage are identified as the active oxidants, and $\mathrm{CO}$ oxidation takes place via a two-steps' mechanism of $\mathrm{CO}+3 \mathrm{OH} \rightarrow \mathrm{COOH}+2 \mathrm{OH} \rightarrow \mathrm{CO}_{2}+$ $\mathrm{H}_{2} \mathrm{O}+\mathrm{OH}$, in which three nearby $\mathrm{OH}$ species are involved in the $\mathrm{CO}_{2}$ formation: $\mathrm{CO}$ reacts with $\mathrm{OH}$, forming $\mathrm{COOH}$; $\mathrm{COOH}$ then transfers the $\mathrm{H}$ to a nearby $\mathrm{OH}$ to form $\mathrm{H}_{2} \mathrm{O}$ and $\mathrm{CO}_{2}$, at the same time, another $\mathrm{H}$ in the $\mathrm{H}_{2} \mathrm{O}$ transfers to a nearby $\mathrm{OH}$ to form a weak adsorbed $\mathrm{H}_{2} \mathrm{O}$ and a new $\mathrm{OH}$. The reaction barrier of these processes is reduced significantly to around $0.50 \mathrm{eV}$. These new results not only provide an insight into surface active oxidants on $\mathrm{Ru}$, which is directly relevant to fuel cell catalysis, but also reveals the extra complexity of catalytic reactions taking place at solid/liquid electrochemical interface in comparison to the relatively simpler ones at solid/gas phase.

Key words:

Ruthenium, Surface oxidants, Carbon monoxide, Electrocatalysis, Density functional theory (DFT), Electrochemical In-situ FTIR

*Corresponding author.

E-mail address: w.lin@qub.ac.uk (W.F.Lin)

Tel:+44 289097 4175; fax: +44 2890976524 


\section{Introduction}

The elementary processes involved in electrocatalysis at solid/liquid interface under electric field and charging conditions are apparently far more complicated than those in heterogeneous catalysis at solid/gas interface. A striking example of the problems introduced by electrochemical interface is presented by the seemingly simple (electro-)oxidation of CO on $\mathrm{Ru}$. In UHV and gas phase studies, Ru(0001) surface has been well documented to be inactive towards CO oxidation under UHV or at low pressure conditions where well ordered oxygen adlayers of (2 x 2)-O and ( $2 \times 1)$-O were formed and CO can coadsorb with these oxygen adlayers occupying mainly linearly (on-top) bonding sites and a minor bridging adsorption sites [1-7]. Saturation of the $\mathrm{Ru}(0001)$ with oxygen results in the formation of an (1 x 1)-O layer, which is still inactive towards $\mathrm{CO}$ oxidation, and a small amount of $\mathrm{CO}$ adsorbates (0.05) was detected to present in a defect sites in the oxygen layer [3]. However, when exposed to large amounts of oxygen at elevated temperatures $(600-800 \mathrm{~K})$, the $\mathrm{Ru}(0001)$ surface was oxidized to form the $\mathrm{RuO}_{2}$ phase with its (110) face oriented parallel to $\mathrm{Ru}(0001)$, this new phase was found to be very active for the conversion of $\mathrm{CO}$ to $\mathrm{CO}_{2}$ due to the presence of Ru coordinative unsaturated sites and the bridge bonded $\mathrm{O}$ [7]. On the other hand, it has been found that a similar ( 2 x 2)-oxygen containing species adlayer as with the gas phase was formed at lower potential region, and the $(1 \mathrm{x} 1)$-oxygen containing species adlayer was formed at higher potential region at room temperature in acidic aqueous solution $[8,9]$, the former was inactive towards CO oxidation as with the gas phase case and CO can coadsorb with them occupying both linearly and three-fold hollow bonding sites, however, it was found that the latter ( $1 \times 1$ )-phase is active towards $\mathrm{CO}$ electrooxidation to $\mathrm{CO}_{2}$ [8-11], in strong contrast with the gas phase case. Nevertheless, the actual nature of the oxygen species involved in the $\mathrm{Ru}(0001)$ electrode reactions and in particular $\mathrm{CO}_{2}$ formation is still missing. Indentifying the oxygen species involved in the electrode reactions is fundamental important for the conceptual understanding of electrocatalysis verse "normal” heterogeneous catalysis and hence is a key challenge in both electrochemistry and surface chemistry studies. This fundamental problem will be addressed in the present study.

We report here using the first principle DFT calculations in combining with electrochemistry, in-situ FTIR spectroscopy and ex-situ electron diffraction data to indentify the surface oxygen species on $\mathrm{Ru}(0001)$ electrode with regard to structure, reactivity and reaction mechanisms during electrosorption of water and CO under electrochemical conditions. It has been shown that both $\mathrm{O}_{\mathrm{ads}}$ and $\mathrm{OH}_{\mathrm{ads}}$ species were formed on the $\mathrm{Ru}(0001)$ electrode, with $(2 \times 2)$ phase 
appeared at lower potential region and $(1 \times 1)$ phase at higher potential region. The $\mathrm{OH}_{\mathrm{ads}}$ species with high coverage, e.g., on $(1 \times 1)$ domains, have been identified as the active oxygen species for the (electro-)oxidation of $\mathrm{CO}$ adsorbates to form $\mathrm{CO}_{2}$, via a two-steps' mechanism, having a low reaction barrier of ca. $0.50 \mathrm{eV}$; whilst the $\mathrm{O}_{\text {ads }}$ species are virtually inactive towards $\mathrm{CO}$ oxidation under all coverages studied, due to the too high reaction barriers $(>1 \mathrm{eV})$ for $\mathrm{CO}$ and $\mathrm{O}$ to react.

\section{Experimental and theoretical}

\section{1 Experimental}

The electrolyte solutions were prepared using Millipore water (18.2 $\mathrm{M} \Omega \mathrm{cm}$ ) and suprapure grade perchloric acid (Merck). $0.1 \mathrm{M} \mathrm{HClO}_{4}$ was employed as the supporting electrolyte. Carbon monoxide (99.0+\%, Aldrich) was used as received. Nitrogen gas from a cryogenic boil-off was employed to de-aerate the solutions and to maintain an air-free atmosphere over the electrolyte during the measurements. All potentials are given vs the standard hydrogen electrode (SHE) although a reference electrode of $\mathrm{Ag} / \mathrm{AgCl}$ in saturated $\mathrm{KCl}$ solution was used. A gold counter electrode was used to avoid Pt contamination. The working electrode was a $\mathrm{Ru}(0001)$ single crystal disc of $7.5 \mathrm{~mm}$ in diameter and $2 \mathrm{~mm}$ thick, it was prepared by the Crystal Laboratory of the Fritz-Haber Institute in Berlin and oriented within $0.5^{\circ}$. As described previously [8-15], the single-crystal surface was freshly polished with $0.015 \mu \mathrm{m}$ alumina (BDH), washed thoroughly with Millipore water and then immersed in Millipore water in an ultrasonic bath for several minutes prior to a rapid transfer into the spectroelectrochemical cell. The quality of the electrode surface was tested by cyclic voltammetry in the supporting electrolyte using the hanging meniscus configuration. The voltammogram obtained for the freshly polished electrode was identical to that observed using the UHVprepared $\mathrm{Ru}(0001)$ electrode [8-21], and was taken as confirmation that a clean and ordered surface had been obtained.

$\mathrm{CO}$ adsorption was performed by dosing the gas at a constant potential of $0 \mathrm{mV}$ vs SHE. For this purpose, $\mathrm{CO}$ was directly bubbled into the $0.1 \mathrm{M} \mathrm{HClO}_{4}$ solution; the $\mathrm{CO}$ in solution was then removed by nitrogen sparging and/or a rapid exchange of electrolyte using $\mathrm{N}_{2}$-saturated base solution. Throughout this adsorption procedure and the subsequent electrolyte replacement, the potential was maintained at $0 \mathrm{mV}$. 
The electrochemical in-situ FTIR experiments were performed using either a BioRad FTS6000 spectrometer equipped with a Globar infrared source and a narrow-band MCT detector or a Varian 670-IR air-bearing FT-IR spectrometer equipped with a Duraglow infrared source and a narrow-band MCT detector, an Autolab PGSTAT302N potentiostat, a home built reflectance optical bench comprising four reflective mirrors and a home-built variable temperature spectro-electrochemical cell fitted with a hemispherical $\mathrm{CaF}_{2}$ window (Medway Optics Ltd)[9, 10]. The cell was mounted vertically on the lid of the sample compartment of the spectrometer, and was designed to allow electrolyte exchange under potential control. The cell was jacketed to allow careful control of the temperature of the electrolyte in the body of the cell. Details of the cell and mounting, as well as the optical bench may be found elsewhere [10, 22]. The reflectance spectra presented below consist of 64 coadded and averaged scans at $8 \mathrm{~cm}^{-1}$ resolution, c. $12 \mathrm{~s}$ per scanset, and are calculated as the ratio $\left(\mathrm{R} / \mathrm{R}_{0}\right)$ vs. $v / \mathrm{cm}^{-1}$, where $\mathrm{R}_{0}$ is the reference spectrum and $\mathrm{R}$ the sample spectra collected as a function of potential or time. This data manipulation results in spectra in which peaks pointing $u p$, to $+\left(\mathrm{R} / \mathrm{R}_{0}\right)$, arise from the loss of absorbing species in $\mathrm{R}$ with respect to $\mathrm{R}_{0}$, and peaks pointing down, to $-\left(\mathrm{R} / \mathrm{R}_{0}\right)$, to the gain of absorbing species.

\section{2 Atomistic modelling and DFT calculations}

All energetic and vibrational calculations reported here were carried out using the VASP package with the employment of a plane wave basis set [23-25]. The generalised gradient approximation (GGA) [26-28] was used to describe the electron exchange and correlation terms with use of the PBE functional [29]. Electron-ion interactions were described using projector-augmented wave (PAW) potential [30]. The convergence of the plane-wave expansion was obtained with a cut-off energy of $500 \mathrm{eV}$. The ground state was determined using Methfessel-Paxton smearing of $0.05 \mathrm{eV}$ [31].

$\mathrm{Ru}(0001)$ surface was modeled using a $(2 \times 2)$ unit cell, the two dimensional Brillouin integrations were fulfilled using a (4 x 4 x 1) Monkhorst-Pack grid[32]. A four-layer slab was employed, with the upper two layers being relaxed and the lower two being in a fixed geometry. Separation of slabs in the normal direction was provided with the use of a $15 \AA$ vacuum region. The lattice constants of the bulk Ru calculated were $2.72 \AA$ (length of side) and $4.31 \AA$ (height), which agree well with $2.71 \AA$ and $4.28 \AA$ [33] of the experimental values.

Adsorption energies were computed by subtracting the energies of the gas-phase molecule and surface from the energy of the adsorption system as $E_{\text {ads }}=E$ (molecule/surface) - 
$\mathrm{E}$ (molecule) - E(surface). With this definition, a negative $E_{\text {ads }}$ corresponds to a stable adsorption on the surface. Using a constrained optimization scheme [34-36], all the transition states (TSs) were searched. All TSs were verified using vibrational frequency analyses (only one negative mode is present at the TS).

For the phase diagrams, $\Delta G$ (Gibbs free energy) for $\mathrm{OH} / \mathrm{O}$ formation was calculated as a function of potential in accordance with the method described by Norskov et al. [37]. $\Delta G$ is calculated for the following reactions (reactions 1 and 2 for $\mathrm{OH}$ and $\mathrm{O}$ formation, respectively):

$$
\begin{aligned}
& \mathrm{H}_{2} \mathrm{O} \rightarrow \mathrm{OH}_{\mathrm{ad}}+\mathrm{H}^{+}+\mathrm{e}^{-} \\
& \mathrm{H}_{2} \mathrm{O} \rightarrow \mathrm{O}_{\mathrm{ad}}+2 \mathrm{H}^{+}+2 \mathrm{e}^{-}
\end{aligned}
$$

Entropy (S) and zero-point energy (ZPE) corrections were calculated from vibrational frequency data using the methods described in a previous work by this group [38]. A pH correction term was calculated to simulate a $\mathrm{pH}$ of 1 (with the calculations being correct for measurements at $\mathrm{pH}$ 0.)

Aqueous environment was modelled in the following procedure: (i) several layers of water molecules with the density of $1 \mathrm{~g} / \mathrm{cm}^{3}$ were placed using the structure of cube ice; (ii) about 25 ps of molecular dynamic (MD) simulations were carried out; (iii) at least six structures selected from MD calculations were optimized and the most stable structure was obtained.

\section{Results and discussion}

\subsection{Identifying the surface oxygen adlayer structures on $R u(0001)$ as a function of potential}

Figure 1 shows the typical cyclic voltammogram obtained from the freshly prepared $\mathrm{Ru}(0001)$ electrode in $0.1 \mathrm{M} \mathrm{HClO}_{4}$ solution. The characteristic redox wave centred near $150 \mathrm{mV}$ may be attributed to the surface oxide/hydroxide formation/reduction [11,39-42]. Previous emersion studies using ex-situ electron diffraction and Auger electron spectroscopy $[8,9,16-$ 18] showed that a well-defined and ordered ( $2 \times 2)$ - oxygen-containing adlayer $\mathrm{O} / \mathrm{OH}$ is present at potentials between 0 and $450 \mathrm{mV}$. The small steady increase in the anodic current 
from $200 \mathrm{mV}$ to $450 \mathrm{mV}$ may be attributed to the increase in the size of the $(2 \times 2)-\mathrm{O} / \mathrm{OH}$ domains. The onset of the second characteristic wave near ca. $450 \mathrm{mV}$ coincides with the formation of a (1 x 1)-O/OH adlayer [8,9,16-18], the steady increase in the anodic current between $750 \mathrm{mV}$ and $850 \mathrm{mV}$ may be attributed to a corresponding increase in the size of the (1 x 1)-O/OH domains. In order to get an insight into the exact nature of the ordered (2 x 2)and $(1 \times 1)$ - adlayers, the phase diagrams of both $\mathrm{O}$ and $\mathrm{OH}$ formations were calculated as a function of potential (see above section 2.2 for calculation details), and Figure 2 and Table 1 show the main data obtained.

It can be seen from Fig. 2 and Table 1 that formation of the $(2 \times 2)-\mathrm{OH}$ and $\mathrm{O}$ species becomes thermodynamically favoured ( $\Delta \mathrm{G}$, Gibbs free energy, is negative) at, and above, the on-set potential of -0.468 and $-0.435 \mathrm{~V}$, respectively. Formation of the $(1 \times 1)-\mathrm{O}$ starts from an onset potential of $0.371 \mathrm{~V}$, and speciation of the $(1 \mathrm{x} 1)-\mathrm{OH}$ sets in at $0.617 \mathrm{~V}$ and above. These data are in good agreement with the above experimental (electrochemical and electron diffraction) results, and confirm that there are mixed $\mathrm{O}$ and $\mathrm{OH}$ species co-adsorbed on the $\mathrm{Ru}(0001)$ surface, with ordered (2 x 2)-O/OH formed at the lower potential region, and (1 x 1)- $\mathrm{O} / \mathrm{OH}$ formed at the higher potential region.

\subsection{CO adsorption and oxidation: structure, reactivity and reaction mechanisms}

The reactivity of the $\mathrm{Ru}(0001)$ electrode towards the adsorption and oxidation of CO was studied by cyclic voltammetry (CV), in-situ FTIR spectroelectrochemistry and DFT atomistic modelling.

In both $\mathrm{CV}$ and FTIR studies, CO adsorption on the Ru(0001) was performed in $0.1 \mathrm{M}$ $\mathrm{HClO}_{4}$ solution by dosing the gas at a constant potential of $0 \mathrm{mV}$ for $5 \mathrm{~min}$ after which the $\mathrm{CO}$ in the solution was removed by nitrogen sparging for $15 \mathrm{~min}$ and/or a rapid exchange of electrolyte using $\mathrm{N}_{2}$-saturated $0.1 \mathrm{M} \mathrm{HClO}_{4}$ solution.

The CO stripping cyclic voltammograms (CVs) are shown in Fig. 3. It can be seen that the electrooxidation of the adsorbed $\mathrm{CO}\left(\mathrm{CO}_{\mathrm{ads}}\right)$ took place relatively slowly at potentials above $400 \mathrm{mV}$, the $\mathrm{CO}_{\mathrm{ads}}$ is not completely removed after the first potential sweep up to $1050 \mathrm{mV}$; in fact only after 7 potential cycles the $\mathrm{CO}_{\mathrm{ads}}$ was completed removed. This is in marked contrast to the polycrystalline Ru electrode, where all the adsorbed CO was eliminated during 
first potential cycle up to $900 \mathrm{mV}[43,44]$. In order to explain the $\mathrm{CV}$ data, and to get an insight into the CO structure on the Ru(0001) electrode, in-situ FTIR studies were performed.

In-situ FTIR spectra were collected at successively higher potentials from $0 \mathrm{mV}$ to $1300 \mathrm{mV}$ in intervals of $50 \mathrm{mV}$, after the $\mathrm{CO}$ adsorption at $0 \mathrm{mV}$ (see above). Figure 4a shows representative spectra collected as a function of potential, whilst figure $4 \mathrm{~b}$ shows the plots of IR band intensities of $\mathrm{CO}$ adsorbates and their oxidation product $\mathrm{CO}_{2}$ in the adjacent solution from the same experiment as a function of potential. The spectra covering the $\mathrm{CO}_{2}$ absorption region, $2250 \mathrm{~cm}^{-1}-2450 \mathrm{~cm}^{-1}$, were normalized to the spectrum collected at $0 \mathrm{mV}$, i.e. prior to the formation of $\mathrm{CO}_{2}$. The spectra covering the $\mathrm{CO}_{\mathrm{ads}}$ spectral region, $1725 \mathrm{~cm}^{-1}-2125$ $\mathrm{cm}^{-1}$, were normalized to the spectrum taken after holding at $1300 \mathrm{mV}$ for 5 minutes at the end of the experiment in order to ensure the complete removal of adsorbed CO. It is clear from fig. 4a that adsorbed CO may be present in linear $\left(\mathrm{CO}_{\mathrm{L}}\right.$, main feature, band at $2000-$ $\left.2045 \mathrm{~cm}^{-1}\right)$ and threefold coordinated $\left(\mathrm{CO}_{\mathrm{H}}, 1765-1805 \mathrm{~cm}^{-1}\right)$ configurations, respectively [9-11]. There are two main effects: The C-O bands (most clearly evident for the linear species, $\mathrm{CO}_{\mathrm{L}}$ ) shift to higher frequencies (i.e., electrochemical Stark effect $[9,45]$ ), and above about $400 \mathrm{mV}$ (most clearly evident at above $600 \mathrm{mV}$, as shown clearly in fig. 4b) their intensities decrease. The field induced blue shift may be attributed to reduction of back-donation of metallic electrons into the antibonding $2 \pi^{*}$ orbital of $\mathrm{CO}$ whereby also the adsorption bond becomes weakened [45]. The decrease of the intensities of the bands of adsorbed CO parallels an increase of the concentration (amount) of $\mathrm{CO}_{2}$ in the adjacent solution (with an IR absorption near $2340 \mathrm{~cm}^{-1}$ [9-11]), as seen more clearly from fig. $4 \mathrm{~b}$, and thus signals the electrocatalytic oxidation of $\mathrm{CO}$ adsorbates to $\mathrm{CO}_{2}$. This result agrees well with the above $\mathrm{CV}$ data where the oxidation current was observed above $400 \mathrm{mV}$.

The above cyclic voltammetry and in-situ FTIR data show that CO can (co-)adsorb with the $(2 \times 2)-\mathrm{O} / \mathrm{OH}$ adlayers (pre-formed with a max coverage up to 0.25 ) on the $\mathrm{Ru}(0001)$ electrode at lower potentials (e.g., $0 \mathrm{mV})$; the $(2 \mathrm{x} 2)-\mathrm{O} / \mathrm{OH}$ are inactive towards $\mathrm{CO}$ oxidation, the oxidation of CO took place at higher potentials where $(1 \mathrm{x}$ 1)-O/OH phases were formed. To support these conclusions and to get a further insight into the reaction mechanisms, we have performed DFT calculations on these co-adsorption systems and on the oxidation reaction processes; and the main results are presented and discussed below.

\subsection{1. $\mathrm{CO}_{a d s}$ oxidation at the presence of $\mathrm{O}$ species}

Figure 5 show the DFT atomistic modelling of $\mathrm{CO}$ co-adsorbs with $\mathrm{O}$ on the $(2 \times 2)-\mathrm{O}$ phase 
and the possible oxidation reaction processes. The optimized geometrical structures show that oxygen occupies the threefold hcp site, and CO occupies the linear on-top site with the carbon atom bonding with Ru surface. Adsorption energies of CO and O (see Table 2) are $1.78 \mathrm{eV}$ and $-2.85 \mathrm{eV}$, respectively, which indicates that $\mathrm{CO}$ and $\mathrm{O}$ can co-adsorb on the Ru surface.

(2×2)-O + CO: It is shown (see fig. 5 a) that starting from the initial state (IS), due to the diffusion, $\mathrm{CO}$ on $\mathrm{Ru}(1)$ atom moves towards the adjacent $\mathrm{Ru}(2)$ atom, which may push $\mathrm{O}$ atom on the threefold hcp hollow site to climb up to the adjacent bridge site, forming a transition state $\mathrm{O}_{(\mathrm{a})} \cdots \mathrm{CO}$ (TS, see fig. 5b), having a bond length between activated $\mathrm{O}\left(\mathrm{O}_{(\mathrm{a})}\right)$ and $\mathrm{C}$ atom of $\mathrm{CO}$ at $1.73 \AA$; this is then followed by the formation of the product $\mathrm{CO}_{2}$ in the final state (FS, see fig. 5c). The reaction barrier calculated between IS and TS is $1.49 \mathrm{eV}$, the value is obviously too high for the reaction to occur at room temperature.

(2×2)-2O + CO: As the coverage of $\mathrm{O}$ phase increases up to $0.5 \mathrm{ML}$, e.g., forming $(2 \times 2)-2 \mathrm{O}$ + CO, CO molecule favours the threefold hcp site, reaching a stable co-adsorption initial state (IS, see fig. 6a). The oxidation reaction proceeds in the similar way as to that of the $(2 \times 2)-\mathrm{O}$ $+\mathrm{CO}$. CO moves up towards the $\mathrm{O}$ atom, which in turn is forced to move to the adjacent bridge site, forming a TS with $1.78 \AA$ of the $\mathrm{O}_{(\mathrm{a})} \cdots \mathrm{CO}$ bonding (see fig. $6 \mathrm{~b}$, it is noted that the half of the unactivated $\mathrm{O}$ atoms remain on the same hollow site); then the formation of the product $\mathrm{CO}_{2}$ follows (see fig. 6c). The reaction barrier calculated is $1.44 \mathrm{eV}$, which is too high for the reaction to take place at room temperature.

(2×2)-3O + CO: As the coverage of O phase further increases, e.g., forming $(2 \times 2)-3 \mathrm{O}+\mathrm{CO}$, which is close to the monolayer ( $1 \times 1$ )-O structure except that one $\mathrm{CO}$ replaced O. For CO oxidation to proceed, a TS with $1.93 \AA$ of the $\mathrm{O}_{(\mathrm{a})} \cdots \mathrm{CO}$ bonding is formed (see fig. 7b, where the unactivated $\mathrm{O}$ atoms remain on the same hollow sites), the reaction barrier calculated is $1.47 \mathrm{eV}$, this is apparently too high for the reaction to proceed at room temperature.

\subsection{2. $\mathrm{CO}_{a d s}$ oxidation in the presence of $\mathrm{OH}$ species}

Figure 8 show the DFT atomistic modelling of $\mathrm{CO}$ co-adsorbs with $\mathrm{OH}$ on the $(2 \times 2)-\mathrm{OH}$ phase and the possible oxidation reaction processes. The optimized geometrical structures 
show that $\mathrm{OH}$ occupies the threefold fcc site, and $\mathrm{CO}$ occupies the linear on-top site with the carbon atom bonding with Ru surface. Adsorption energies of $\mathrm{CO}$ and $\mathrm{OH}$ (see Table 2) are $1.86 \mathrm{eV}$ and $-3.43 \mathrm{eV}$, respectively, which indicates that $\mathrm{CO}$ and $\mathrm{OH}$ can co-adsorb on the $\mathrm{Ru}$ surface.

In contrast to the simple one step CO oxidation via only one TS in CO + O system, see above and ref [46], for the $\mathrm{CO}+\mathrm{OH}$ system, it has been shown that two steps of $\mathrm{CO}+\mathrm{OH} \rightarrow$ $\mathrm{COOH}$ and then $\mathrm{COOH} \rightarrow \mathrm{CO}_{2}+\mathrm{H}$ are included in the $\mathrm{CO}$ oxidation reaction [47].

$(2 \times 2)-\mathbf{O H}+\mathbf{C O}$ : As the starting point, $\mathrm{CO}$ molecule co-adsorbs on the $(2 \times 2)-\mathrm{OH}$ phase, the optimized IS (see fig. 8a) shows that CO preferably binds to the on-top site of $\mathrm{Ru}(1)$ atom with the $\mathrm{C}-\mathrm{Ru}(1)$ bonding length of $1.875 \AA$, whereas $\mathrm{OH}$ occupies on the adjacent threefold fcc hollow site with the O-Ru(2) distance of $2.196 \AA$, $2.182 \AA$ and $2.193 \AA$. For CO oxidation to occur, $\mathrm{CO}$ needs to move towards the adjacent $\mathrm{Ru}(2)$ atom (see fig. 8b), which in turn pushes the $\mathrm{OH}$ previously occupying the fcc hollow site to climb up and take the top site nearby, at the TS-I both $\mathrm{CO}$ and $\mathrm{OH}$ are on off-top sites, tilting away from each other. The distance between the $\mathrm{C}$ in the $\mathrm{CO}$ and the $\mathrm{O}$ in the $\mathrm{OH}$ is $1.760 \AA$, which is stretched by $40 \%$ compared to the bond length $(1.258 \AA)$ of $\mathrm{OC}-\mathrm{OH}$ in cis $\mathrm{COOH}$ in the gas phase. The calculated reaction barrier (obtained between IS and TS-I) is $1.20 \mathrm{eV}$. After the TS-I, the CO and $\mathrm{OH}$ move together/closer, forming $\mathrm{COOH}$ (see fig. 8c, named FS-I), the bond length of OC-OH reduced to $1.45 \AA$, which is closer to that of the gas phase $\mathrm{COOH}$ as mentioned above. Interestingly, during the formation process of $\mathrm{COOH}$ species, it is found that the length of C-O in CO increases slightly from $1.174 \AA$ to $1.213 \AA$; however, no significant change (from $0.975 \AA$ to $0.986 \AA$ ) occurs to the $\mathrm{O}-\mathrm{H}$ in $\mathrm{OH}$ species. Subsequently, dehydrogenation of $\mathrm{COOH}$ species takes place as shown in fig.8d where the $\mathrm{H}$ atom rotates and points down to the same $\mathrm{Ru}$ atom binding to the $\mathrm{O}$ of the $\mathrm{OH}$ of the $\mathrm{COOH}$, which apparently causes the site competition in the COO $\cdots \mathrm{H}$ (see fig. 8d, named TS-II). The O-H distance of the $\mathrm{COO} \cdots \mathrm{H}$ is increased to $1.34 \AA$ from $0.986 \AA$ of the $\mathrm{COOH}$ as seen in FS-I, the reaction barrier (between FS-I of $\mathrm{COOH}$ and TS-II of COO $\cdots \mathrm{H}$ ) is $0.95 \mathrm{eV}$. After the TSII, $\mathrm{CO}_{2}$ formation may be followed with the $\mathrm{H}$ atom moving down to the preferable fcc site. The overall CO oxidation in the $(2 \times 2)-\mathrm{OH}+\mathrm{CO}$ phase has a barrier of $1.20 \mathrm{eV}$ to overcome, which is too high for the reaction to occur at room temperature. 
$(2 \times 2)-2 O H+C O$ : For the optimized structure of IS (see fig. 9a), CO preferably binds to the top site of $\mathrm{Ru}(1)$ atom with the distance of $\mathrm{C}-\mathrm{Ru}(1)$ of $1.934 \AA$, which is slightly longer than that in the lower $\mathrm{OH}$ coverage phase as reported above, this is probably due to the interaction of extra adjacent $\mathrm{OH}$ species here; whereas there are two $\mathrm{OH}$ groups around the $\mathrm{CO}$, one of these occupies the adjacent bridge site (yielding $2.116 \AA$ and $2.138 \AA$ of the distances between $\mathrm{O}$ and the two Ru atoms), and the other one takes the top site (with $2.018 \AA$ of O-Ru binding). Interestingly the $\mathrm{H}$ atom of the bridging $\mathrm{OH}$ species points to the $\mathrm{O}$ atom of the top $\mathrm{OH}$ specie, implying that there is certain attractive interaction between them (e.g., $\mathrm{H}$ bonding). For $\mathrm{CO}$ oxidation to proceed, $\mathrm{CO}$ moves towards the adjacent $\mathrm{Ru}(2)$ atom (see fig. $9 b)$, which forces the $\mathrm{OH}$ previously occupying the bridging site to climb up and take the top site nearby, the later in turn pushes away the other $\mathrm{OH}$ group previously occupying the top site to bridging site (see fig. 9b). At the TS-I, both $\mathrm{CO}$ and $\mathrm{OH}$ are on top sites, tilting away from each other. The bond length between the $\mathrm{C}$ in the $\mathrm{CO}$ and the $\mathrm{O}$ in the $\mathrm{OH}$ is $1.800 \AA$, which is stretched by $43 \%$ compared to that of $\mathrm{OC}-\mathrm{OH}$ in cis $\mathrm{COOH}$ in the gas phase. The calculated reaction barrier is $0.72 \mathrm{eV}$. After the TS-I, the $\mathrm{C}$ of $\mathrm{CO}$ and the $\mathrm{O}$ of $\mathrm{OH}$ move closer whilst the $\mathrm{O}$ of $\mathrm{CO}$ and the $\mathrm{H}$ of $\mathrm{OH}$ rotate away, forming $\mathrm{COOH}$ (see fig. 9c, the FS-I). It is noted that, although the extra $\mathrm{OH}$ group did not involve in the oxidation process, it may stabilize the TS-I such reduces the reaction barrier from $1.20 \mathrm{eV}$ of the (2 x 2)-OH case to the $0.72 \mathrm{eV}$ here, the optimized structure of $\mathrm{COOH}$ species here has also a different orientation and surface bonding from that on the $(2 \times 2)-\mathrm{OH}$ phase. Subsequently dehydrogenation of $\mathrm{COOH}$ species takes place as shown in fig. $9 \mathrm{~d}$ where the $\mathrm{C}$ atom and $\mathrm{O}$ atom of $\mathrm{CO}$ share the same $\mathrm{Ru}(2)$ atom whereas $\mathrm{H}$ atom binds to the adjacent $\mathrm{Ru}$ atom, which forms the TS-II of $\mathrm{COO} \cdots \mathrm{H}$. The bonding distance of $\mathrm{COO} \cdots \mathrm{H}$ is $1.40 \AA$, and the energy barrier between $\mathrm{COOH}$ (FS-I) and COO $\cdots \mathrm{H}$ (TS-II) is $1.00 \mathrm{eV}$. After TS-II, $\mathrm{CO}_{2}$ formation follows with the $\mathrm{H}$ atom moving down to the preferable hcp site.

$(2 \times 2)-3 \mathbf{O H}+\mathbf{C O}$ : $\mathrm{CO}$ co-adsorbs on the $(2 \times 2)-3 \mathrm{OH}$ phase forming compact adlayer (see fig. 10a), which has the highest local $\mathrm{OH}$ coverage similar to $(1 \mathrm{x} 1)-\mathrm{OH}$ adlayer except one $\mathrm{OH}$ is replaced by CO, the optimized IS (see fig.10a) shows that CO, as well as OH, preferably binds to the bridge site between $\mathrm{Ru}(1)$ and $\mathrm{Ru}(2)$ atoms. Interestingly the $\mathrm{H}$ atom of all bridging $\mathrm{OH}$ species points to the same direction. For $\mathrm{CO}$ oxidation to proceed, $\mathrm{CO}$ at the bridging site moves to the one adjacent $\mathrm{Ru}(2)$ atom and takes the top site, which in turn pushes one adjacent bridging $\mathrm{OH}$ to transfer to top site, the $\mathrm{CO}$ subsequently moves towards the opposite bridging $\mathrm{OH}$ species, forming transition state TS-I (see fig. 10b). The bonding 
distance between the $\mathrm{C}$ of $\mathrm{CO}$ and the $\mathrm{O}$ of $\mathrm{OH}$ is $1.840 \AA$, and the reaction barrier is $0.53 \mathrm{eV}$. After the TS-I, formation of $\mathrm{COOH}$ (as FS-II, see fig. 10c) being followed, it occupies the hollow site having the $\mathrm{C}$ atom bonded to one $\mathrm{Ru}$ atom. It is also noted that the previous bridge $\mathrm{OH}$ species now is stabilized on the top site. Subsequently dehydrogenation of $\mathrm{COOH}$ species takes place with the $\mathrm{C}$ atom binds to $\mathrm{Ru}(2)$ atom whereas the $\mathrm{H}$ atom binds to the adjacent $\mathrm{Ru}$ atom which is shared by $\mathrm{O}$ atom of the $\mathrm{OH}$ of the $\mathrm{COOH}$, forming the TS-II of $\mathrm{COO} \cdots \mathrm{H}$ (see fig. $10 \mathrm{~d}$ ). The COO $\cdots \mathrm{H}$ bond length is $1.08 \AA$, and the reaction energy barrier between $\mathrm{COOH}(\mathrm{FS}-\mathrm{I})$ and $\mathrm{COO} \cdots \mathrm{H}$ (TS-II) is $0.54 \mathrm{eV}$. After the TS-II, $\mathrm{CO}_{2}$ formation is followed with $\mathrm{H}$ atom moving towards the adjacent bridging $\mathrm{OH}$, forming $\mathrm{H}-\mathrm{OH}$ (i.e., $\mathrm{H}_{2} \mathrm{O}$ on bridge site) specie, which in turn transfer its another $\mathrm{H}$ to the nearby on-top $\mathrm{OH}$ to form a new $\mathrm{H}_{2} \mathrm{O}$ (on top site, having a weaker bonding to the surface than that on bridge site) and recovered a bridging $\mathrm{OH}$. Apparently the reaction barrier of $0.53 \mathrm{eV}$ for the $\mathrm{CO}$ oxidation at the presence of high coverage $\mathrm{OH}$ is low enough for the oxidation reaction to occur at room temperature. This relatively low energy barrier may be attributed to the chain reactions and the H-bonding which help to stabilise the TSs and reduce reaction barriers. Thus the DFT results not only agree well with the in-situ FTIR spectroelectrochemical data, but also help to identify the active surface oxidant of $\mathrm{OH}$ with a high local coverage, and to reveal the complexity of the surface processes in the CO oxidation reactions.

\section{Concluding remarks}

In conclusion, our combined studies of DFT calculations and in-situ FTIR spectroelectrochemistry on surface oxidants and mechanisms of CO oxidation at Ru(0001) electrode reveal that surface $\mathrm{O}$ species are not the active oxidants under all coverages studied due to the high reaction barriers $(>1 \mathrm{eV})$, whilst surface $\mathrm{OH}$ species with higher coverage are identified as the active oxidants, and CO oxidation takes place via a two-steps' mechanism of $\mathrm{CO}+3 \mathrm{OH} \rightarrow \mathrm{COOH}+2 \mathrm{OH} \rightarrow \mathrm{CO}_{2}+\mathrm{H}_{2} \mathrm{O}+\mathrm{OH}$, in which three nearby $\mathrm{OH}$ species are involved in the $\mathrm{CO}_{2}$ formation: $\mathrm{CO}$ reacts with $\mathrm{OH}$, forming $\mathrm{COOH}$; $\mathrm{COOH}$ then transfers the $\mathrm{H}$ to a nearby $\mathrm{OH}$ to form $\mathrm{H}_{2} \mathrm{O}$ and $\mathrm{CO}_{2}$, at the same time, another $\mathrm{H}$ in the $\mathrm{H}_{2} \mathrm{O}$ transfers to a nearby $\mathrm{OH}$ to form a weak adsorbed $\mathrm{H}_{2} \mathrm{O}$ and a new $\mathrm{OH}$. The reaction barrier to overcome is around $0.50 \mathrm{eV}$ which is relative low, indicating that the oxidation reaction can take place at the room temperature. These new results not only provide an insight into surface active oxidants on $\mathrm{Ru}$, which is directly relevant to fuel cell catalysis, but also reveals the 
extra complexity of catalytic reactions taking place at solid/liquid electrochemical interface in comparison to the relatively simpler ones occurring at solid/gas phase.

\section{Acknowledgements}

We gratefully acknowledge financial support from the EPSRC (TS/H001875/1 and EP/I013229/1). W. F. Lin would like to thank Professor G. Ertl from Fritz-Haber-Institute and Professor Z. W. Tian from Xiamen University, for many very useful and inspiring discussions.

\section{References}

[1] K. L. Kostov, H. Rauscher, D. Menzel, Surf. Sci. 278 (1992) 62.

[2] A. Schiffer, P. Jakob, D. Menzel, Surf. Sci. 389 (1997) 116.

[3] C. Stampfl, S. Schwegmann, H. Over, M. Scheffler, G. Ertl, Phys. Rev. Lett. 77 (1996) 3371.

[4] A. Boettcher, H. Niehus, S. Schwegmann, H. Over, G. Ertl, J. Phys. Chem. B 101 (1997) 11185.

[5] A. Boettcher, M. Rogozia, H. Niehus, H. Over, G. Ertl, J. Phys. Chem. 103 (1999) 6267.

[6] M. Bonn, S. Funk, Ch. Hess, D. N. Denzler, C. Stampfl, M. Scheffler, M. Wolf, G. Ertl, Science 285 (1999) 1042.

[7] H. Over, Y. D. Kim, A. P. Seitsonen, S. Wendt, E. Lundgren, M. Schmid, P. Varga, A. Morgante, G. Ertl, Science 287 (2000) 1474.

[8] W. F. Lin, M. S. Zei, Y. D. Kim, H. Over, G. Ertl, J. Phys. Chem. B 104 (2000) 6040.

[9] W. F. Lin, P. A. Christensen, A. Hamnett, M. S. Zei, G. Ertl, J. Phys. Chem. B 104 (2000) 6642.

[10] W. F. Lin, P. A. Christensen, A. Hamnett, J. Phys. Chem. B 104 (2000) 12002.

[11] J. M. Jin, W. F. Lin, P. A. Christensen, J. Electroanal. Chem. 563 (2004) 71.

[12] W. F. Lin, P. A. Christensen, A. Hamnett, Phys. Chem. Chem. Phys. 103 (2001) 3312.

[13] W. F. Lin, P. A. Christensen, Faraday Discuss. 121 (2002) 267.

[14] W. F. Lin, J. M. Jin, P. A. Christensen, K. Scott, Electrochim. Acta 48 (2003) 3815.

[15] J. M. Jin, W. F. Lin, P. A. Christensen, Phys. Chem. Chem. Phys. 10 (2008) 3774.

[16] M. S. Zei, G. Ertl, Phys. Chem. Chem. Phys. 2 (2000) 3855. 
[17] W. B. Wang, M. S. Zei, G. Ertl, Phys. Chem. Chem. Phys. 3 (2001) 3307.

[18] J. Lee, W. B. Wang, M. S. Zei, G. Ertl, Phys. Chem. Chem. Phys. 4 (2002) 1393.

[19] W. B. Wang, M. S. Zei, G. Ertl, Chem. Phys. Lett. 355 (2002) 301.

[20] P. C. Lu, C. H. Yang, S. L. Lin, M. S. Zei, Langmuir 18 (2002) 754.

[21] S. R. Brankovic, N. S. Marinkovic, J. X. Wang, R. R. Adzic, J. Electroanal. Chem. 532 (2002) 57.

[22] P. A. Christensen, J. Eameaim, A. Hamnett, Phys. Chem. Chem. Phys. 1 (1999) 5315.

[23] G. Kresse, J. Hafner, Phys. Rev. B 47 (1993) 558.

[24] G. Kresse, J. Hafner, Phys. Rev. B 48 (1993) 13115.

[25] G. Kresse, J. Hafner, Phys. Rev. B 49 (1993) 14251.

[26] J. P. Perdew, J. A. Chevary, S. H. Vosko, K. A. Jackson, M. R. Pederson, D. J. Singh, C. Fiolhais, Phys. Rev. B 46 (1992) 6671.

[27] P. Hu, D. A. King, S. Crampin, M. H. Lee, M. C. Payne, Chem. Phys. Lett. 230 (1994) 501.

[28] J. P. Perdew, Electronic Structure in Solids' 91 Akademie Verlag: Berlin (1991).

[29] J. P. Perdew, Y. Wang, Phys. Rev. B 45 (1992) 13244.

[30] G. Kresse, D. Joubert, Phys. Rev. B 59 (1999) 1758.

[31] M. Methfessel, A. T. Paxton, Phys. Rev. B. 40 (1989) 3616.

[32] H. J. Monkhorst, J. D. Pack, Phys. Rev. B 13 (1976) 5188.

[33] C. Stampfl, M. Scheffler, Phys. Rev. B 54 (1996) 2868.

[34] A. Alavi, P. Hu, T. Deutsch, P. L. Sylvestrelli, J. Hutter, Phys. Rev. Lett. 80 (1998) 3650.

[35] A. Michaelides, P. Hu, J. Am. Chem. Soc. 122 (2000) 9866.

[36] Z. P. Liu, P. Hu, J. Am. Chem. Soc. 125 (2003) 1958.

[37] J. Rossmeisl, J. K. Norskov, C. D. Taylor, M. J. Janik, M. Neurock, J. Phys. Chem. B 110 (2006) 21833.

[38] X. M. Cao, R. Burch, C. Hardacre, P. Hu, Catal. Today 165 (2011) 71.

[39] A. M. El-Aziz, L. A. Kibler, Electrchem. Comm. 4 (2002) 866.

[40] H. E. Hoster, M.J. Janik, M. Neurock, R. J. Behm, Phys. Chem. Chem. Phys. 12 (2010) 10388

[41] O. B. Alves, H. E. Hoster, R. J. Behm, Phys. Chem. Chem. Phys. 13 (2011) 6010.

[42] M. T. M. Koper, Electrochim. Acta. 56 (2011) 10645.

[43] W. F. Lin, T. Iwasita, W. Vielstich, J. Phys. Chem. B 103 (1999) 3250.

[44] W. F. Lin, M. S. Zei, M. Eiswirth, G. Ertl, T. Iwasita, W. Vielstich, J. Phys. Chem. B 103 (1999) 6968. 
[45] S. A. Wassileski, M. T. M. Koper, M. J. Weaver, J. Phys. Chem. B 105 (2001) 3518.

[46] G. Ertl, Faraday Discuss. 121 (2002) 1.

[47] Y. H. Fang, G. F. Wei, Z. P. Liu, Catalysis Today, in press (2012) DOI:10.1016/j.cattod.2012.04.055. 
Table 1 The onset potentials $\mathrm{U}_{0}$ (V vs. SHE) of respective O/OH phases formed on the $\mathrm{Ru}(0001)$.

\begin{tabular}{c|c}
\hline Phases & $\mathrm{U}_{0}$ \\
\hline$(2 \times 2)-\mathrm{O}$ & -0.435 \\
$(2 \times 2)-\mathrm{OH}$ & -0.468 \\
& \\
$(1 \times 1)-\mathrm{O}$ & 0.371 \\
$(1 \times 1)-\mathrm{OH}$ & 0.617 \\
\hline
\end{tabular}

Table 2 Adsorption and co-adsorption energies $(\mathrm{eV})$ of $\mathrm{CO}, \mathrm{O}$ and $\mathrm{OH}$ molecule on $\mathrm{Ru}(0001)-\mathrm{p}(2 \times 2)$ unit cell (1/4 ML coverage).

\begin{tabular}{ll}
\hline Species & $\Delta \mathrm{E}_{\mathrm{ads}}$ \\
\hline $\mathrm{CO}$ alone & $-1.86_{\text {(top })}$ \\
O alone & -2.92 \\
$\mathrm{OH}$ alone & -3.54 \\
$\mathrm{CO}+\mathrm{O}$ & $-1.78(\mathrm{CO}),-2.85(\mathrm{O})$ \\
$\mathrm{CO}+\mathrm{OH}$ & $-1.86(\mathrm{CO}),-3.43(\mathrm{OH})$ \\
\hline
\end{tabular}




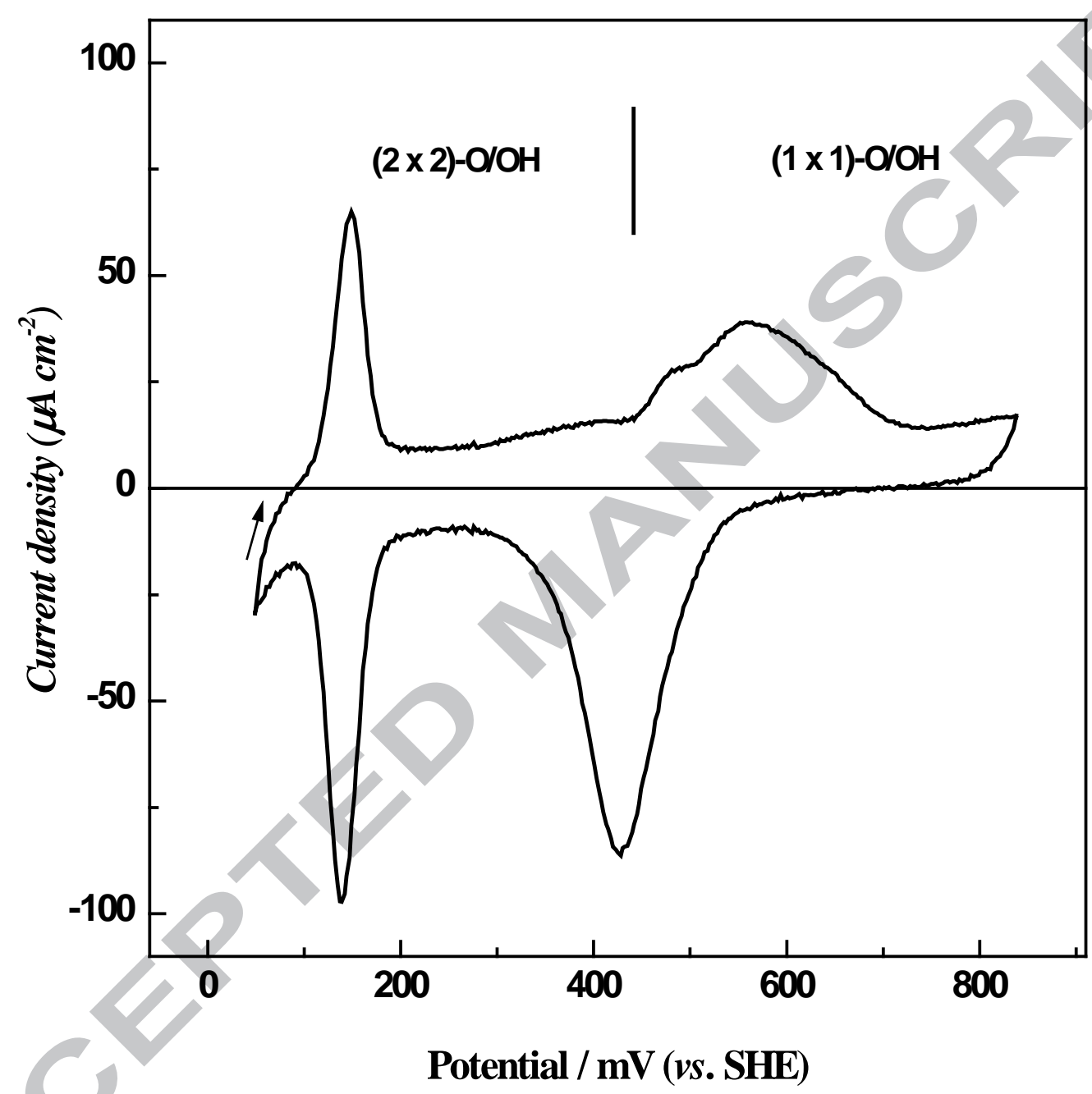

Fig. 1. Cyclic voltammogram of the freshly prepared $\mathrm{Ru}(0001)$ electrode $\left(0.44 \mathrm{~cm}^{2}\right)$ immersed in $\mathrm{N}_{2}$-saturated aqueous $0.1 \mathrm{M} \mathrm{HClO}_{4}$ solution at $20{ }^{\circ} \mathrm{C}$. Sweep rate $50 \mathrm{mV} \mathrm{s}^{-1}$. The surface hydroxide/oxide adlayers formed are indicated in the plot. 


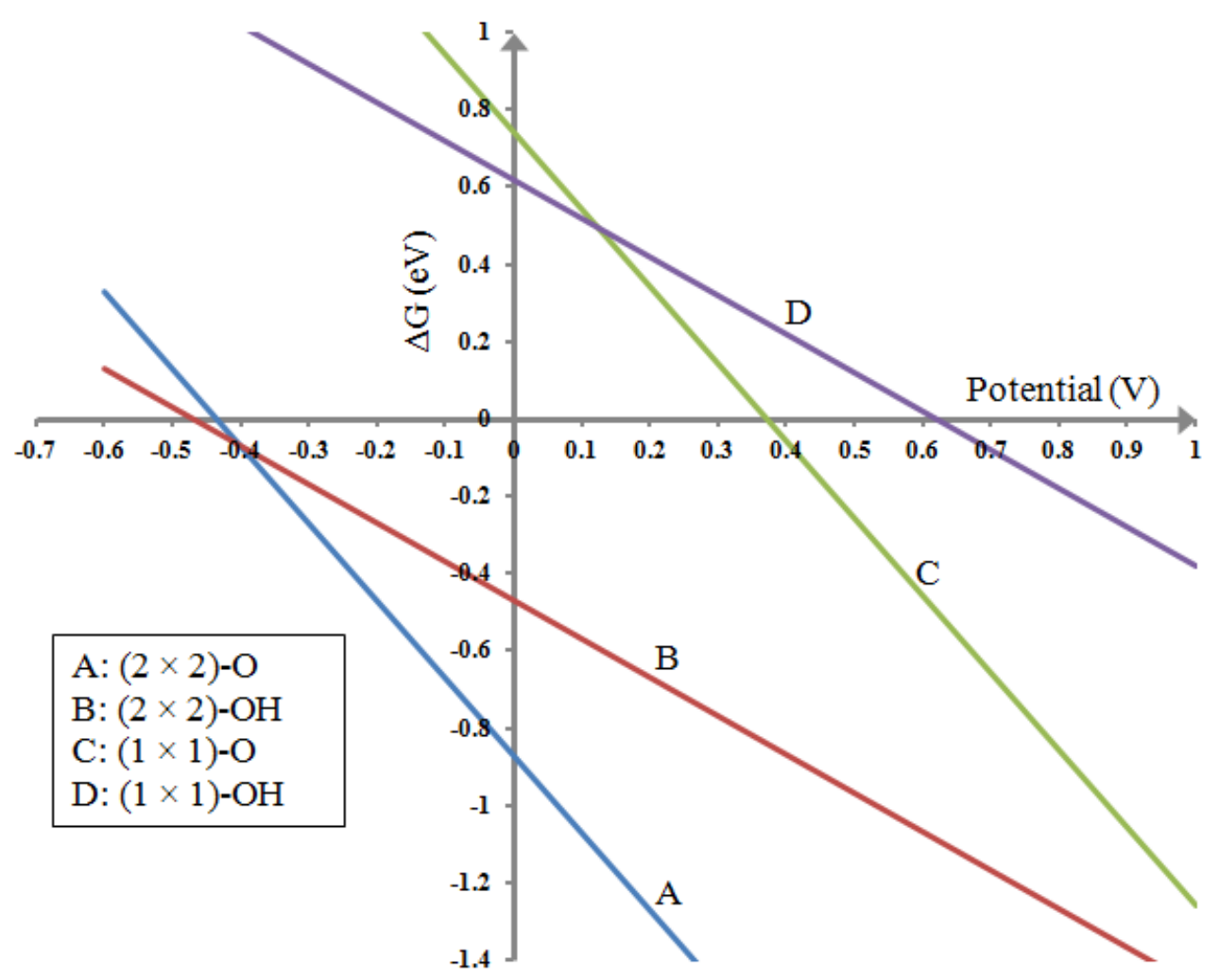

Fig. 2 Phase diagram for (2 x 2)-O (A), (2 x 2)-OH (B), (1 x 1)-O (C) and (1 x 1)-OH (D) formation on the $\mathrm{Ru}(0001)$ surface showing $\Delta \mathrm{G}$ as a function of potential vs. SHE under standard temperature and pressure and at $\mathrm{pH}=1$. Both $\mathrm{O}$ and $\mathrm{OH}$ species adopt a threefold hollow site. The x-intercept of the line indicates the potential at which formation becomes thermodynamically favoured, or the onset potential of speciation. 


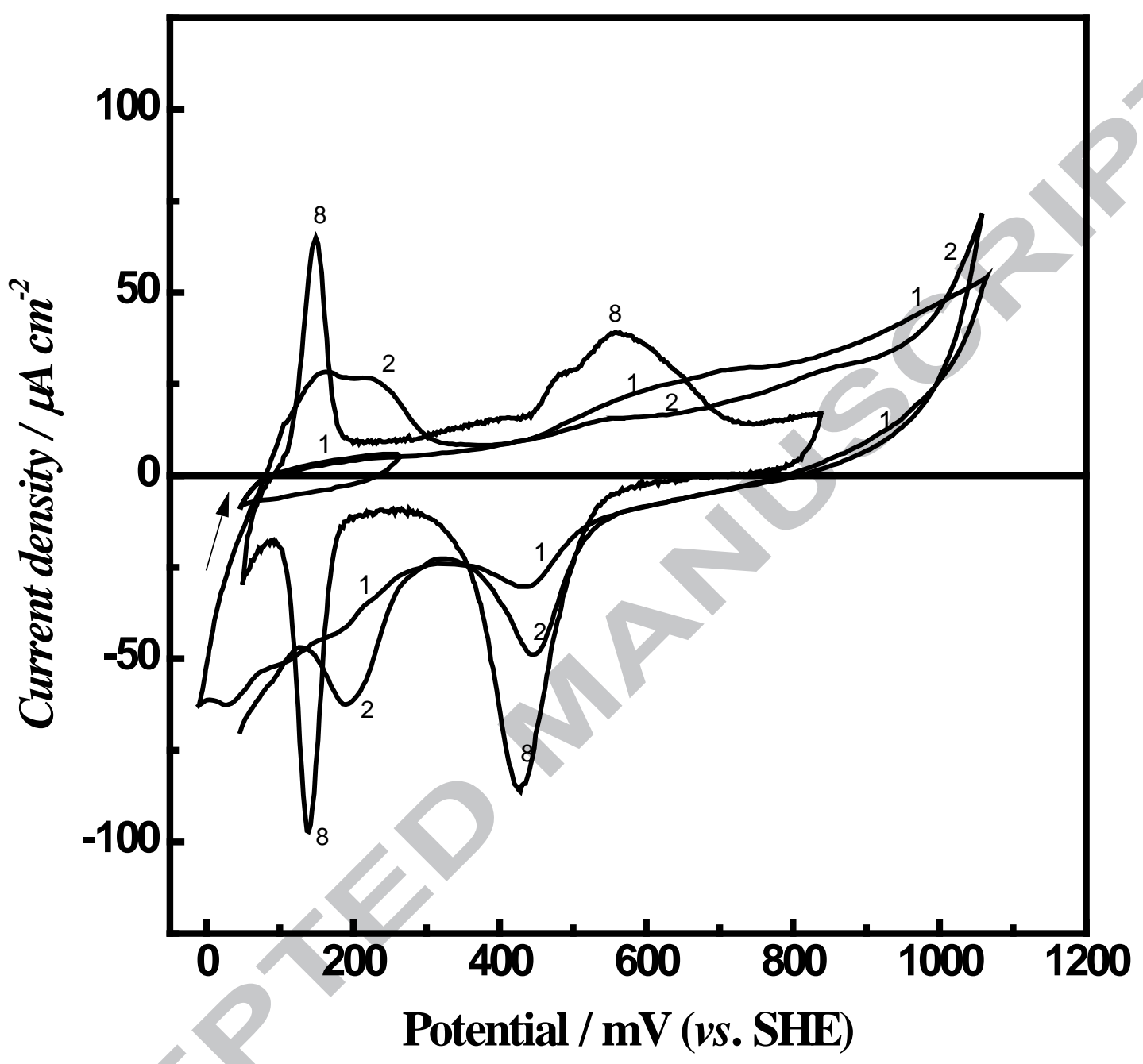

Fig. 3. Cyclic voltammograms showing the oxidative stripping of the pre-adsorbed CO adlayer from the $\mathrm{Ru}(0001)$ electrode in aqueous $0.1 \mathrm{M} \mathrm{HClO}_{4}$ (CO-free) electrolyte. The CO was adsorbed from the CO-saturated electrolyte at $0 \mathrm{mV}$ for 5 minutes, after which the solution was replaced with CO-free electrolyte. The numbers refer to the sequence of potential cycles; some cycles are omitted for clarity. Sweep rate $50 \mathrm{mV} \mathrm{s}^{-1}$. 


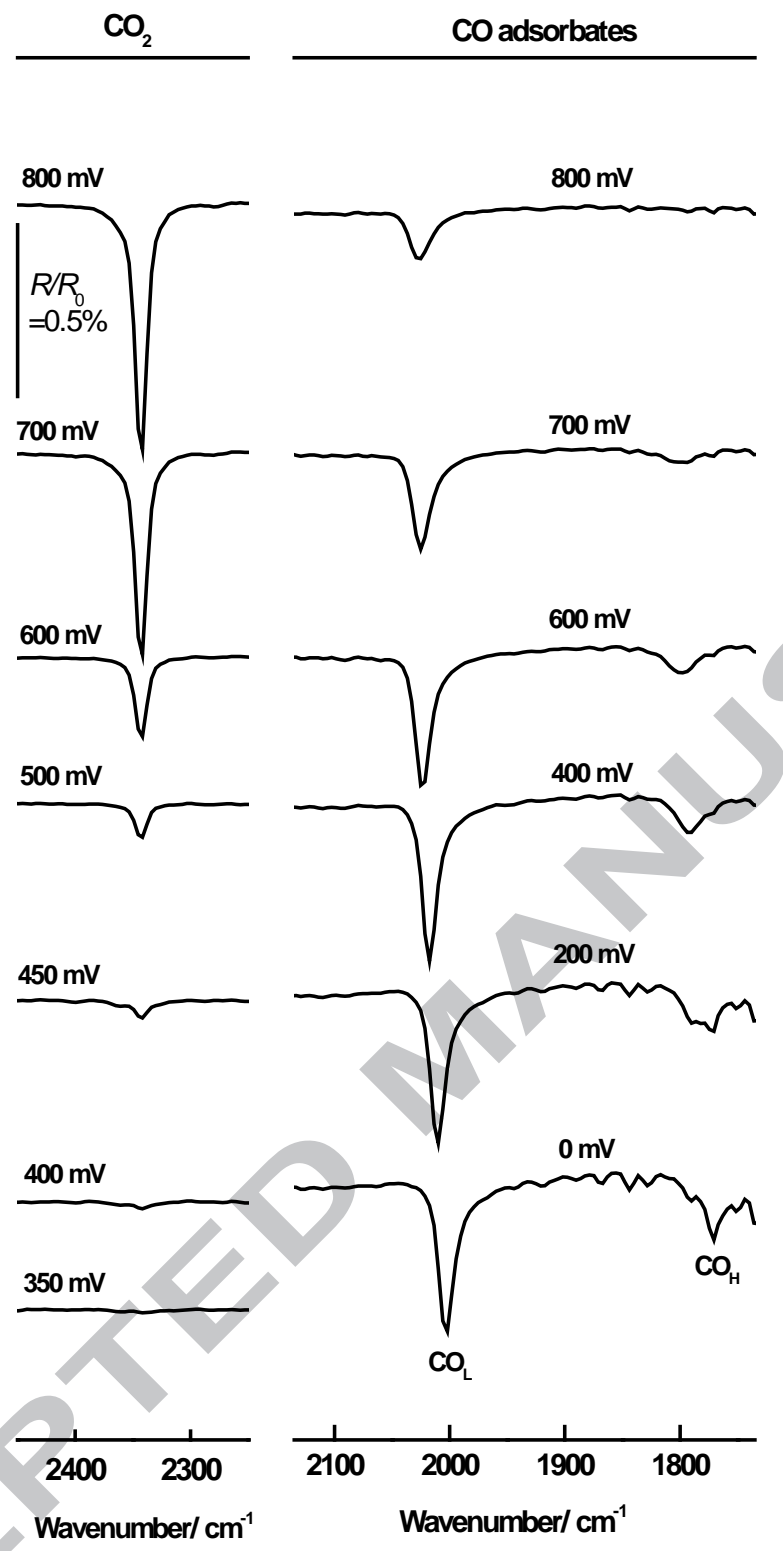

Fig. 4a. In-situ FTIR spectra collected from the $\mathrm{Ru}(0001)$ electrode in $0.1 \mathrm{M} \mathrm{HClO}_{4}$ solution at $20{ }^{\circ} \mathrm{C}$ during a potential step experiment after the adsorption of $\mathrm{CO}$. The $\mathrm{CO}$ was preadsorbed at $0 \mathrm{mV}$, after which the solution was sparged with $\mathrm{N}_{2}$ (see text for details), the potential was then stepped up to $+1300 \mathrm{mV}$ in $50 \mathrm{mV}$ increments, with further spectra collected at each step. The spectra showing the $\mathrm{CO}_{2}$ absorption were normalised to the first spectrum, collected at $0 \mathrm{mV}$. The spectra showing the $\mathrm{CO}$ absorption were normalised to a spectrum taken after holding the potential at $+1300 \mathrm{mV}$ for $3 \mathrm{~min}$ at the end of the experiment, to ensure the electrode surface was free of adsorbed CO. Some of the spectra collected are omitted for the sake of clarity. 


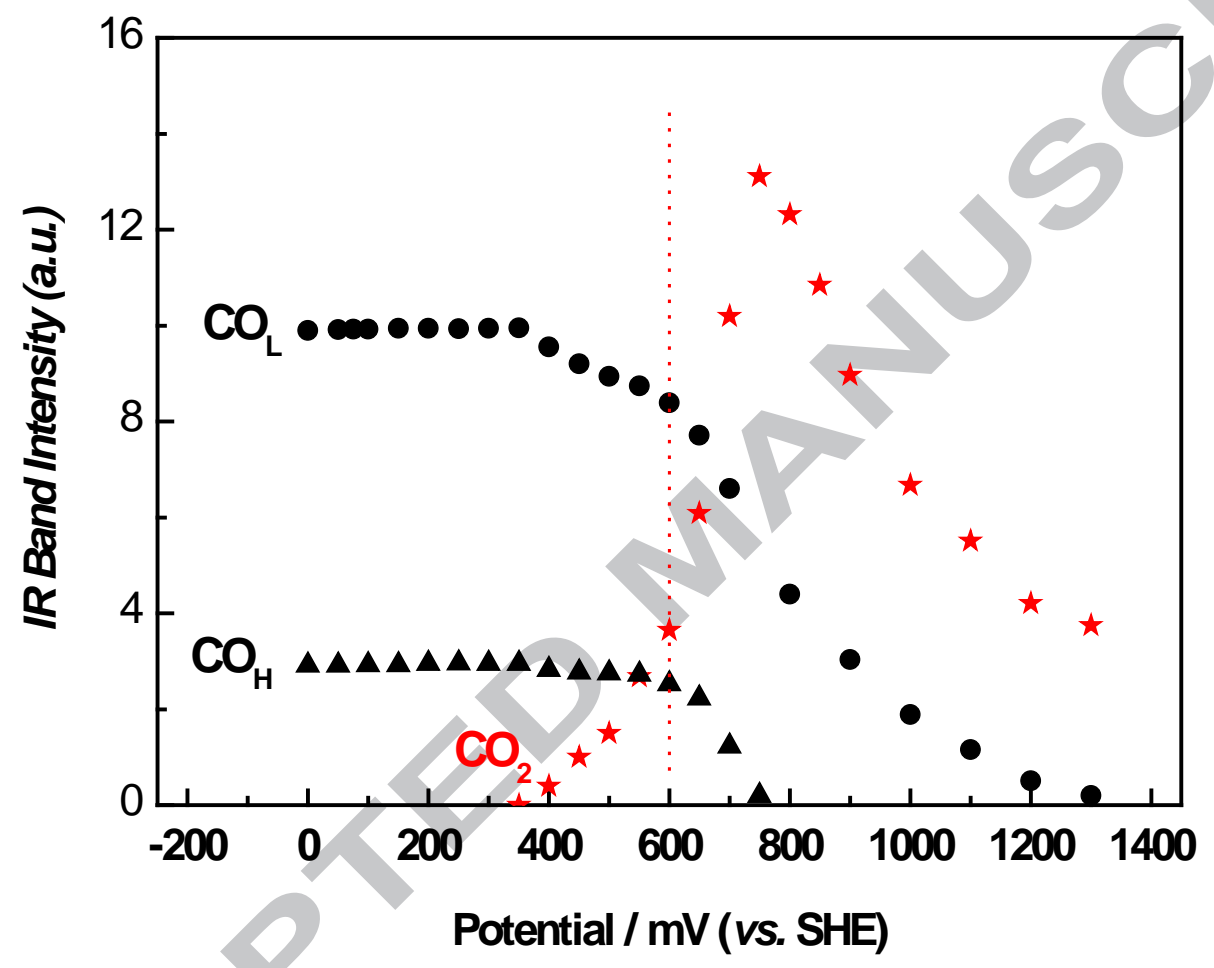

Fig. 4b. Plots of the IR band intensities of the $\mathrm{CO}_{\mathrm{L}}, \mathrm{CO}_{\mathrm{H}}$ and $\mathrm{CO}_{2}$ features in fig. $4 \mathrm{a}$ as a function of potential. 

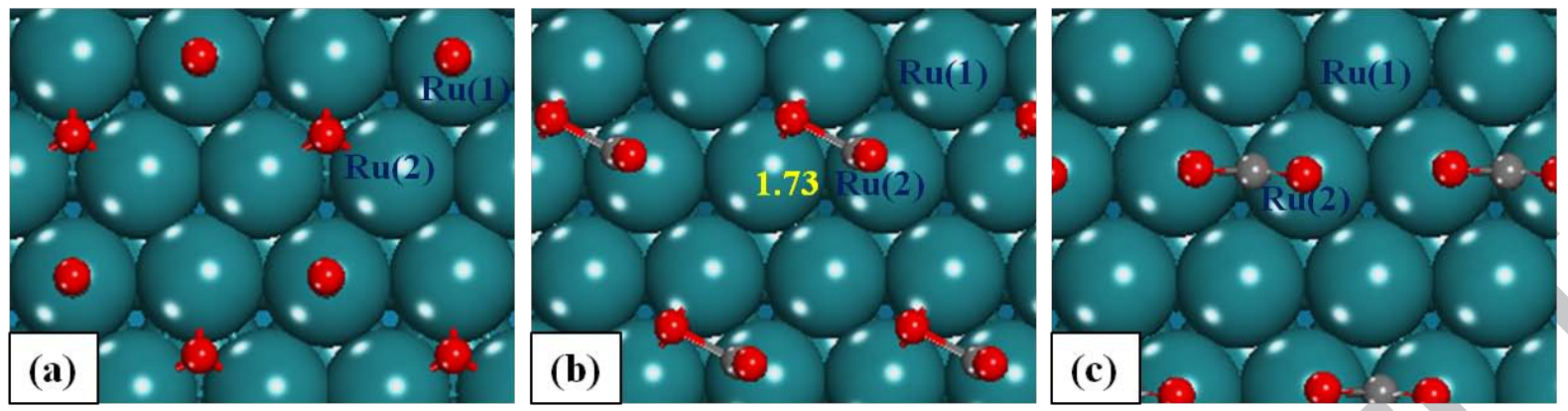

Figure 5. DFT atomistic modelling shows a top view of the $(2 \times 2)-\mathrm{O}+\mathrm{CO}$ co-adsorption and CO oxidation process. (a) Initial State (IS): O + CO; (b) Transition State (TS): O $\cdots$ CO; (c) Final State (FS): $\mathrm{CO}_{2}$. Oxygen atoms are shown in red, carbon atoms are in gray, and $\mathrm{Ru}$ atoms are in green.
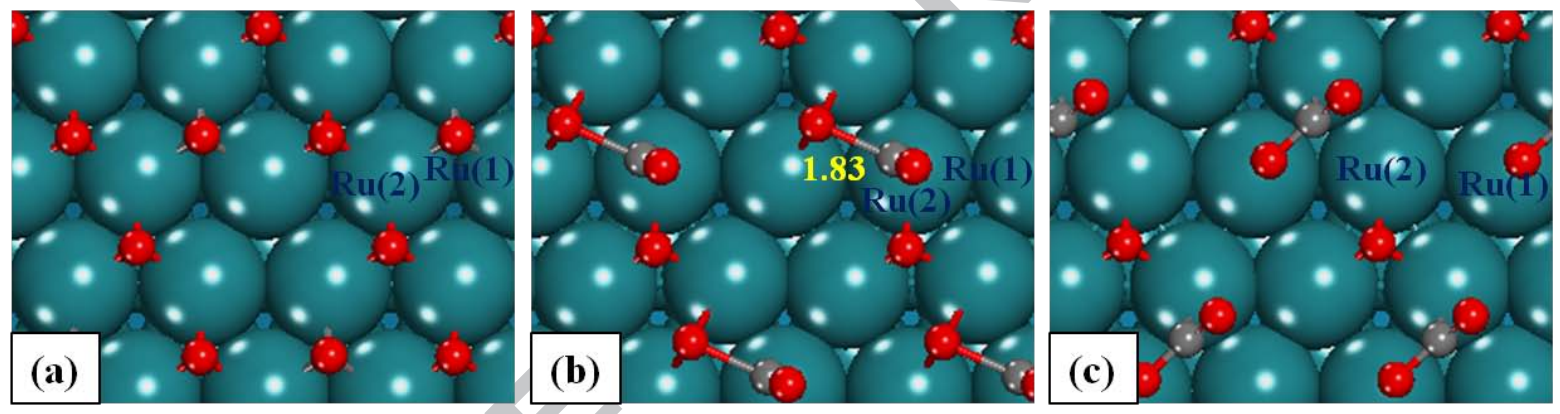

Figure 6. DFT atomistic modelling shows a top view of the $(2 \times 2)-2 \mathrm{O}+\mathrm{CO}$ co-adsorption and CO oxidation process. (a) Initial State (IS): $2 \mathrm{O}+\mathrm{CO}$; (b) Transition State (TS): O + $\mathrm{O} \cdots \mathrm{CO}$; (c) Final State (FS): $\mathrm{O}+\mathrm{CO}_{2}$. Oxygen atoms are shown in red, carbon atoms are in gray, and Ru atoms are in green.
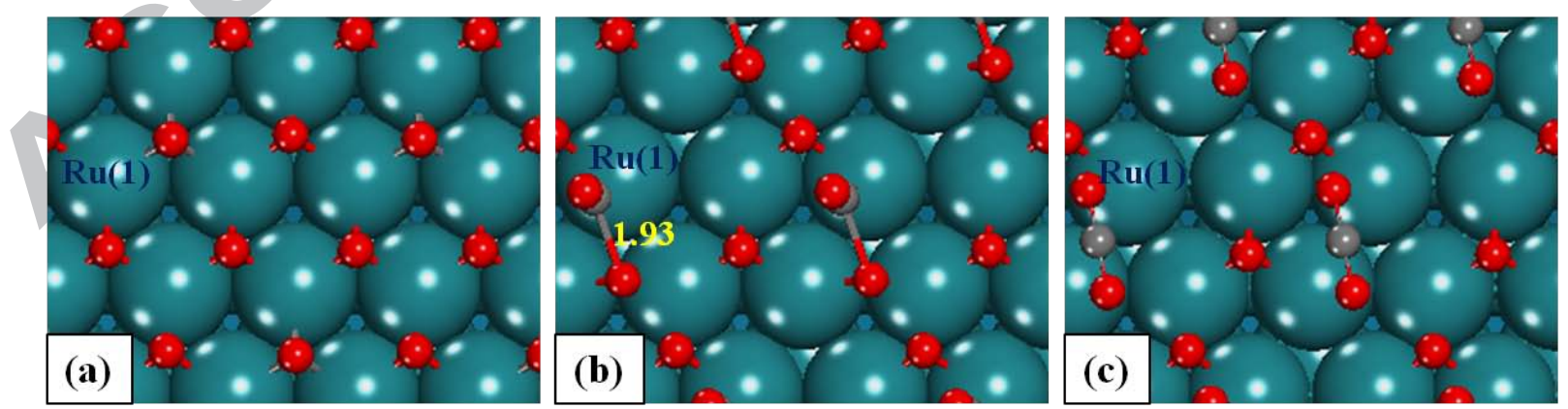

Figure 7. DFT atomistic modelling shows a top view of the $(2 \times 2)-3 \mathrm{O}+\mathrm{CO}$ co-adsorption and CO oxidation process. (a) Initial State (IS): $3 \mathrm{O}$ + CO; (b) Transition State (TS): $2 \mathrm{O}+$ $\mathrm{O} \cdots \mathrm{CO}$; (c) Final State (FS): $2 \mathrm{O}+\mathrm{CO}_{2}$. Oxygen atoms are shown in red, carbon atoms are in gray, and Ru atoms are in green. 

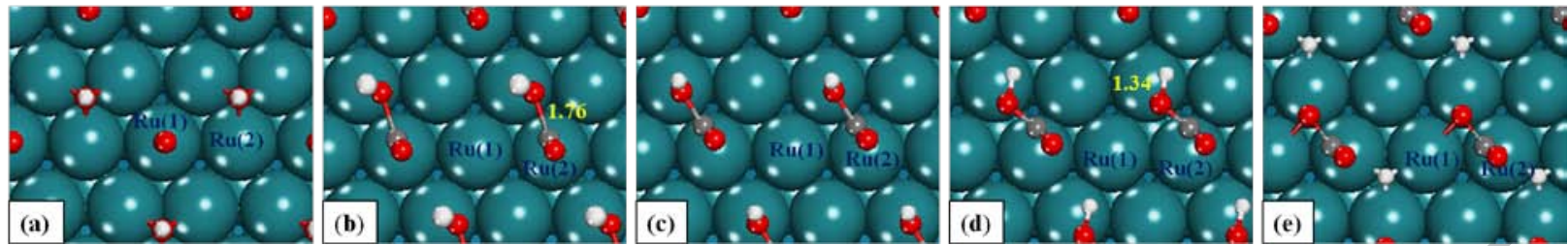

Figure 8. DFT atomistic modelling shows a top view of the $(2 \times 2)-\mathrm{OH}+\mathrm{CO}$ co-adsorption and CO oxidation process. (a) Initial State (IS): OH + CO; (b) Transition State I (TS-I): HO $\cdots$ CO; (c) Final State I (FS-I): COOH; (d) TS-II: OCO $\cdots$ H; (e) FS-II: $\mathrm{CO}_{2}+$ H. Oxygen atoms are shown in red, hydrogen atoms are shown in white, carbon atoms are in gray, and $\mathrm{Ru}$ atoms are in green.
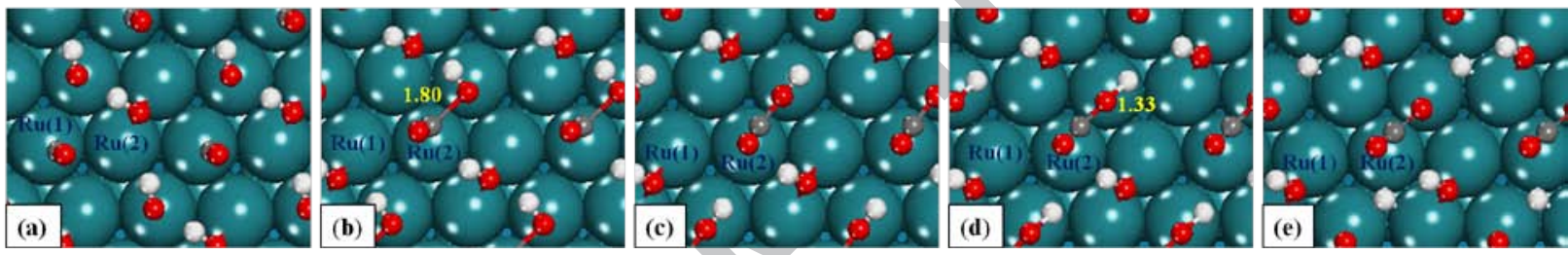

Figure 9. DFT atomistic modelling shows a top view of the $(2 \times 2)-2 \mathrm{OH}+\mathrm{CO}$ co-adsorption and $\mathrm{CO}$ oxidation process. (a) Initial State (IS): $\mathrm{OH}+\mathrm{OH}+\mathrm{CO}$; (b) Transition State I (TS-I): $\mathrm{OH}+\mathrm{HO} \cdots \mathrm{CO}$; (c) Final State I (FS-I): $\mathrm{OH}+\mathrm{COOH}$; (d) TS-II: OH + OCO $\cdots \mathrm{H}$; (e) FS-II: $\mathrm{OH}+\mathrm{CO}_{2}+\mathrm{H}$. Oxygen atoms are shown in red, hydrogen atoms are shown in white, carbon atoms are in gray, and $\mathrm{Ru}$ atoms are in green.
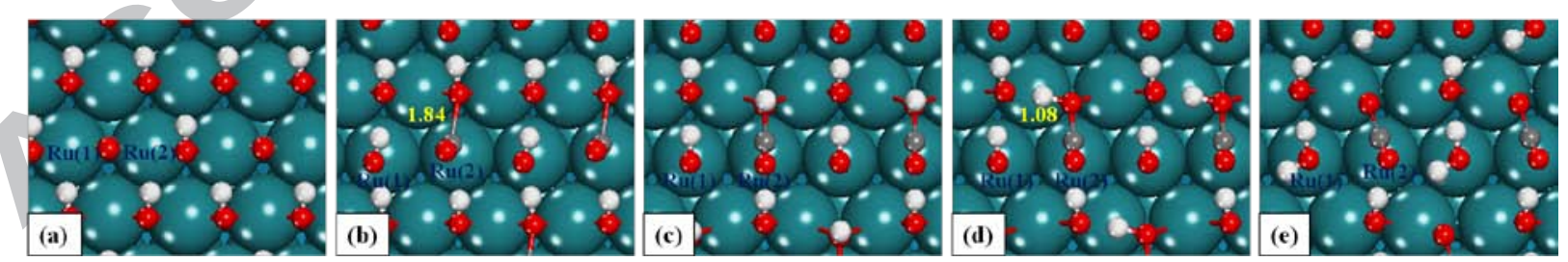

Figure 10. DFT atomistic modelling shows a top view of the $(2 \times 2)-3 \mathrm{OH}+\mathrm{CO}$ co-adsorption and CO oxidation process. (a) Initial State (IS): $3 \mathrm{OH}+\mathrm{CO}$; (b) Transition State I (TS-I): OH $+\mathrm{OH}+\mathrm{HO} \cdots \mathrm{CO}$; (c) Final State I (FS-I): $\mathrm{OH}+\mathrm{OH}+\mathrm{COOH}$; (d) TS-II: $\mathrm{OH}+\mathrm{OH}+$ OCO $\cdots \mathrm{H}$; (e) FS-II: $\mathrm{CO}_{2}+\mathrm{H}_{2} \mathrm{O}+\mathrm{OH}$. Oxygen atoms are shown in red, hydrogen atoms are shown in white, carbon atoms are in gray, and $\mathrm{Ru}$ atoms are in green. 


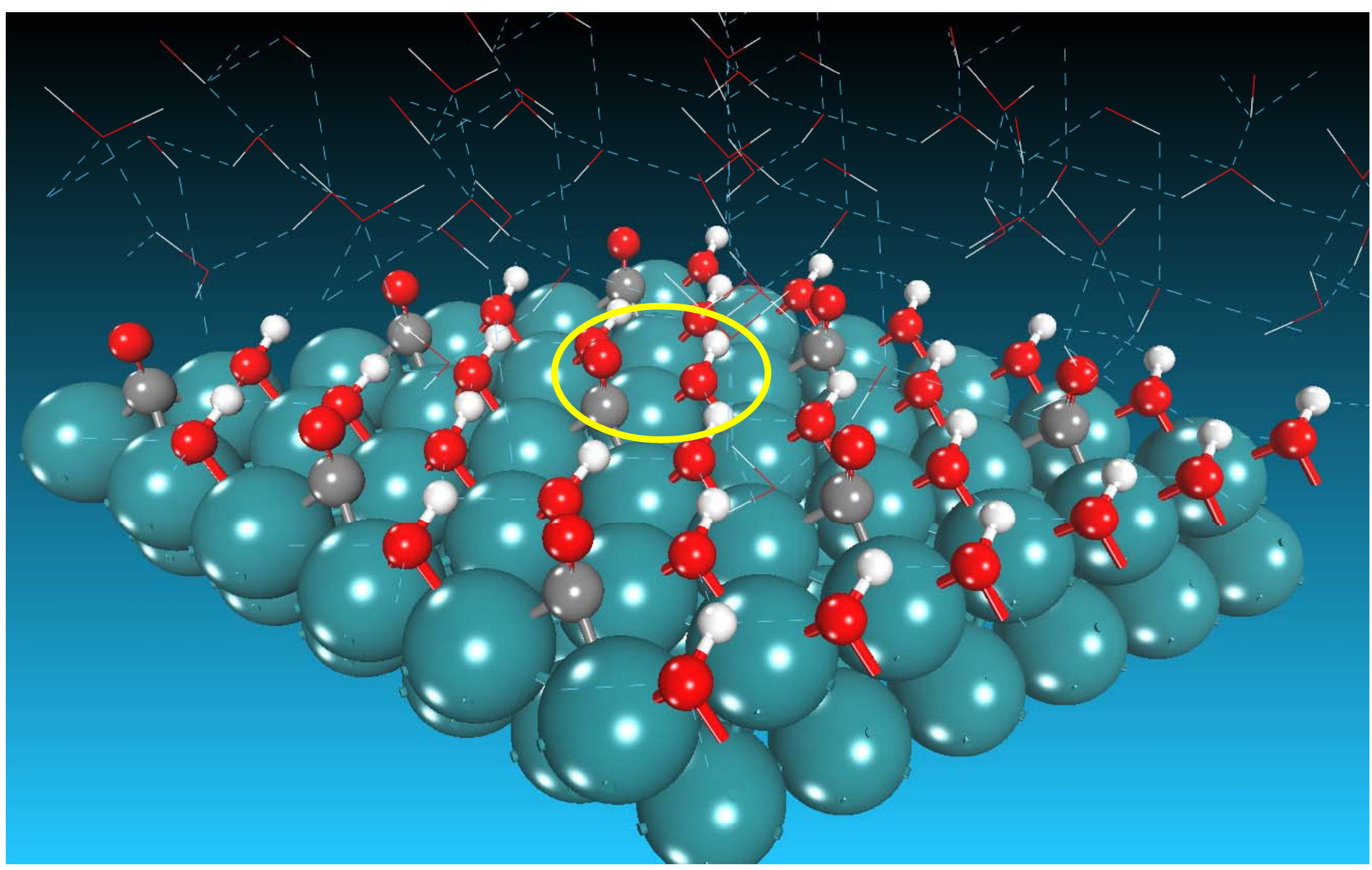




\section{Research Highlights:}

- Combined studies of DFT and in-situ FTIR on surface oxidants and CO oxidation at Ru.

- Surface $\mathrm{O}$ is not the active oxidants.

- Surface $\mathrm{OH}$ with high coverage is identified as the active oxidants.

- $\mathrm{CO}$ oxidation takes place via $\mathrm{COOH}$ in a two-step's mechanism.

- Three $\mathrm{OH}$ species may be involved in the $\mathrm{CO}_{2}$ formation. 